Article

\title{
"Festivalisation" of Urban Governance in South African Cities: Framing the Urban Social Sustainability of Mega-Event Driven Development from Below
}

\author{
Matthias Fleischer ${ }^{*}$, Maximilian Fuhrmann ${ }^{\dagger}$, Christoph Haferburg ${ }^{\dagger}$ and Fred Krüger ${ }^{\dagger}$ \\ Institute of Geography, University of Erlangen-Nuremberg, Kochstraße 4/4, Erlangen 91054, Germany; \\ E-Mails: mfuhrmann@geographie.uni-erlangen.de (M.F.); chaferburg @ geographie.uni-erlangen.de (C.H.); \\ fkrueger@geographie.uni-erlangen.de (F.K.)
}

$\dagger$ These authors contributed equally to this work.

* Author to whom correspondence should be addressed; E-Mail: matthias.fleischer@ fau.de; Tel.: +49-9131-85-22656; Fax: +49-9131-85-22633.

Received: 13 September 2013; in revised form: 31 October 2013 / Accepted: 21 November 2013 / Published: 9 December 2013

\begin{abstract}
This article is based on field research in two South African host cities of the Men's Football World Cup 2010 (eThekwini and Johannesburg). The discussed work is part of the research project "Festivalisation" of Urban Governance: The Production of Socio-Spatial Control in the Context of the FIFA World Cup 2010 in South Africa. In the context of mega-events, impacts and changes on urban development can vary on a spectrum of festivalisation between opposing poles, either "driven by the event", or on the other hand where existing configurations of actors and established policies are "driving the event". By drawing on a theoretical framework which is inspired by an analytical understanding of urban governance, our assumptions are that (a) different configurations of governance promote different ways of handling the challenges associated to the hosting and (b) that different types of "festivalisation" have different consequences and effects for the lived realities of the residents at a local level. The latter is an arena in which urban governance policies are translated, adapted, renegotiated or rejected. We argue that the bringing together of both spheres (local and metropolitan) provides a profound understanding of the process of mega-event implementation and its relation to urban social sustainability.
\end{abstract}

Keywords: festivalisation; urban governance; South Africa; Football World Cup; Johannesburg; eThekwini; Durban; urban social sustainability; dis-/order; neighborhood 


\section{Introduction}

The relation between mega-events and urban development has been discussed for the past twenty years with an increasing awareness of the implications for urban policies. Most of the literature has been focusing on mega-events in the "global north". Those events are said to have been instrumentalized by city authorities and politicians to promote specific local agendas of inter alia economic growth, infrastructure projects and place branding. Although the sustainability of impacts and legacies in these fields is highly contested by ex-post evaluations [1-7] the success story of mega-events has not been questioned in earnest. Indeed, the competition to become a future host seems to have increased around the globe, and is especially gaining ground in emerging nations of the "Global South" [8,9]. Hence, there has been a debate if the implications for this new type of host cities are similar to those in the "global north", or if a new kind of understanding is required.

"Ke nako-Africa's time has come" was the slogan that was coined to formulate the ambitious backdrop against which South Africa successfully bid for hosting the Men's Football World Cup 2010. The aim was no less than carrying out the event on behalf of the whole continent, sending confidence from "the Cape to Cairo", and creating social and economic opportunities throughout Africa [10]. Nevertheless and in the end, it was the nine host cities that had to deliver not only the event itself, but also the legacy from the local to the global scale. Though being committed to the common goal of integrating the apartheid city and undoing the social, economic and spatial yoke of institutionalized "racial" divisions (cf. [11]), each of the hosting urban arenas is built along an individual path of historical developments which leads to very diverse settings of urban governance. Thus, the World Cup was staged in nine different urban settings according to not only generalized requirements formulated by international actors (in the respective case the Fédération Internationale de Football Association (FIFA)), but also international consultants translating the conditions of the content provider into site-specific policies and by-laws, e.g., exclusion zones and so forth see for example ([12]).

The South African context of hosting provides for a specific emphasis on the socio-spatial production of the "urban"-given that in a post-apartheid situation, social inclusivity, or, broadly speaking, social sustainability has to set a benchmark for any intervention as big as a mega-event. Then again, the respective cities' development trajectories have to be taken into account-especially, if metropolitan municipalities with wide reaching powers of local government are discussed. We will thus link the reflections on the event's urban social sustainability to an analytical perspective which takes the localized complexities of event-related developments and interventions into consideration: the way in which the "festivalisation of urban governance" depends on and is embedded in fine grained local settings [13,14]. Our perspective on urban governance is analytical, defining it as "organized efforts to manage the course of events in a social system" [15]. Thus, we include the production of dis-/order to achieve desired ends, as well as the disputes about the envisaged outcomes in our focus of research. The concept of governance may not be a consistent theory in itself but serves as a framework to facilitate the identification of key actor configurations and further enables us to focus on local-specific settings without losing sight of the national and global sphere alike.

Translating this into the debate on urban social sustainability consequently asks for shifting perspectives of evaluation: Social sustainability cannot be measured or assessed by itself, but within the existing framework of urban governance. Thus, social sustainability needs to be understood as a 
qualifier of existing policies and governance structures within the inquiry on socio-spatial exclusion in the city. It should not be understood as a precisely defined normative goal that is formulated in an abstract way before analyzing the metropolitan structures in their relation to the development of society (cf. only [16]). Our approach on social sustainability rests on the integration of a) the multi-scalar web of actors, mandates and decisions, b) the socio-spatial path dependency of the city itself, and c) the specific challenges that existing structures of urban governance are facing. Thus and in relation to the overall theme of this special issue, we argue in our paper that the effects of mega-event hosting on urban development have to be understood in the light of respective strengths and weaknesses of the specific types of urban governance in any given host city.

\subsection{A World Class Desire: Hosting the World Cup in South African Metropoles}

Our empirical data derives from research on two South African host cities, Johannesburg and eThekwini [17]. Thus, the paper's focus is closely linked to particular South African ways of steering urban development - a setting that can be described as characterized by area-based interventions, spatial control and a multiplicity of actors and institutions from the global to the local scale. These strategies of urban development are set on the backdrop of colonial and apartheid legacies, which were both based very much on social as on spatial engineering [14]. Today's post-apartheid cities still bear the scars of this, but additionally, there has been an impact of almost two decades of market-oriented upgrading policies that were accompanied by a lack of coherent metropolitan development strategies and a sometimes derelict degree of municipal performance [18]. Urban policy in South Africa's metropoles continues to be influenced by the desire to develop world class cities, which is critically assessed by the question if those cities are "for all" [19].

Nevertheless, the definition of social justice and strategies to achieve it are not only linked to the "world class" urban governance discourse on the metropolitan scale, but also to the path-dependent, fine-grained urban fabric of residents and communities, streets and buildings, places and spaces [14,20-22]. Therefore, urban governance in South African cities is embedded in contested spaces and arenas along a global-local interface where global(ized) interests and agendas are confronted by, or merged with, diverse (and sometimes contradictory) ideas on national and/or local scales. In South Africa, the political debate on the steering of urban development tends to be a very sensitive framing of policies in the making: planning practices which evolved in order to cope with this fragmentation are still partly woven into a field of socio-spatial policies inscribed into the cityscapes where cities and citizens continue to experience significant divisions and inequality. In terms of the municipalities' mandate to counteract socio-spatial exclusion and marginalization, South Africa's White Paper on Local Government sets the scale with a clear-cut definition of a Developmental Local Government as the political principle for urban governance:

"Developmental local government is local government committed to working with citizens and groups within the community to find sustainable ways to meet their social, economic, and material needs and improve the quality of their lives." [11].

Thus, externally constructed and initiated modifications of ordering attempts such as World Cup-related interventions are met by a complex web of local understandings, trajectories, and practices of how to 
frame, shape and control city space [23,24]. This dialectic relationship in spatial scales within the perspective on mega-event development and urban politics in South Africa seems to be increasingly defined by attracting investment through urban entrepreneurialism [25]. In this context, Harvey [26] emphasizes the role of attracting spectacles and mega-events like the Olympics within the logics of constant capital accumulation and city competition and criticizes the highly speculative legacies for urban development (cf. also [27]). From this debate derives the perspective that the hosting of megaevents comes along with and is increasingly brought about by a shift within the regimes of urban governance from the global to the local scale. Surborg, et al. [28] for example contextualize the Olympics in the light of transnational policy transfer in urban growth machines and regimes, while Andranovich, et al. [29] turn their focus towards local urban development which riskily follows the lines of stimulating local economic growth through mega-event driven global competition.

Moving beyond this, the work by Kassens-Noor [30] forms the backdrop against which this article with its local-specific cases is interconnected with the larger debate on urban governance and mega-event driven development. Informed by empirical examples of infrastructure planning and development, the author highlights the crucial role of international actors such as the International Olympic Committee (IOC) as stakeholders in the planning process of mega-events, bringing along the “institutional power and necessary tools to influence the host cities' urban planning process". In South Africa, the Football World Cup is managed and carried out as it travels through external actors (in the given case, FIFA, as well as international architecture and planning companies, as well as consultants are outstanding examples) from a global scale into the national, metropolitan and local levels of politics and society [31], thereby bringing along concepts, ideas and technologies of socio-spatial order that can influence the cityscape far beyond the actual event. In this context and inspired by the discussions laid out by Smith [32,33], we try to approach questions of socio-spatial dis-/order by including aspects of urban governance, its evolution and metamorphism, and its effects and contributions to socially sustainable development. Before moving on to the empirical examples, the following paragraph provides a brief overview of the literature on urban social sustainability and sketched out desiderata that frame the featured case studies.

\subsection{Concretizing Urban Social Sustainability and the South African Context}

Since the days of the Brundtland Commission [34] and its effort to holistically formulate a vision for a common global future in economic, environmental and social terms, key aspects of global development have shifted from an "end-of-the-world-scenario" to a more differentiated as well as fragmented debate on globalization and glocalization (cf. [35]). An increasing number of scholars try to theorize and conceptualize the underrepresented aspect of social sustainability, by stressing the nexus of society and culture, and trying to integrate it into a multi-dimensional concept of sustainable development (see amongst others [35-38]). These attempts are being criticized under different aspects. Bramley et al. [39] put their observations in a nutshell: "While there is widespread agreement that a social dimension is important, there is less agreement, and less systematic analysis, of what exactly is meant by social sustainability in different contexts" [39]. This points to the fact that existing concepts lack operationalization and measurability, and this is faced by a variety of contributions which 
predominantly refer to social capital (as described by Coleman [40] and Putnam [41]) as a yardstick for social sustainability [35-37,42].

To reduce the distance between efforts engaging with social sustainability through means of metatheoretical abstractions on the one hand and the clear-cut formulations of normative aims on the other, it might be useful to contextualize the debate by introducing the concepts of "the urban" and of "urbanity". Over the past decade, urban centers have become the dominant type of habitat while social practices in a globalized information age are shaped by and do shape cities [35]. Yiftachel and Hedgcock [43] thus suggest that the city's role as a "long-term viable setting for human interaction, communication, and cultural development" should form the core of a concept of social sustainability. Urban social sustainability would then not only refer to city life, but would play an increasing role for defining social sustainability in general. Addressing specifically urban settings, Stren and Polèse [44] attempt to sketch out a working definition:

"Social sustainability for a city is defined as development (and/or growth) that is compatible with the harmonious evolution of civil society, fostering an environment conducive to the compatible cohabitation of culturally and socially diverse groups while at the same time encouraging social integration, with improvements in the quality of life for all segments of the population."

Here, the authors provide a normative definition of urban social sustainability, which links developmental processes (harmonious evolution and integration of the society) with anticipated aims (cohabitation and quality of life) which shall be made possible in a holistic way (for all segments of the population) while maintaining perceptions of cultural and social diversity and the segmentation of society. Following this possible conceptualization, they further elaborate on the achievement of objects by reducing exclusion of marginalized and disadvantaged groups in society, as well as its social and spatial de-fragmentation, which makes social sustainability the "polar opposite" of exclusion in territorial as well as social terms (see also [35,44]). The latter is of striking importance as it approaches a definition of social sustainability (in the urban realm) "ex negative", thus indicating the issues that touch the realm of social sustainability within urban settings. Moreover, it opens up the socio-spatial dimension of the urban arena by acknowledging that the driving forces that strive between the poles of exclusion and social sustainability consist of territorial and social elements alike.

This argument can be brought forward by bringing it together with a more specific approach as sketched out by Dempsey et al. [45]. They provide a very useful overview of literature on urban social sustainability by extracting various factors of measuring urban social sustainability (see Table 1) (for another overview see [46]).

Table 1. Factors contributing to urban social sustainability. (Source: [45].)

\begin{tabular}{ll}
\hline \multicolumn{1}{c}{ Non-physical factors } & \multicolumn{1}{c}{ Predominantly physical factors } \\
\hline Education and training & Urbanity \\
Social justice: inter- and intra-generational & Attractive public realm \\
Participation and local democracy & Decent housing \\
Health, quality of life and well-being & Local environmental quality and amenity \\
Social inclusion (and eradication of social & Accessibility (e.g., to local services and \\
exclusion) & facilities/employment/green space) \\
Social capital & Sustainable urban design \\
\hline
\end{tabular}


Table 1. Cont.

\begin{tabular}{ll}
\hline \multicolumn{1}{c}{ Non-physical factors } & \multicolumn{1}{c}{ Predominantly physical factors } \\
\hline Community & Neighborhood \\
Safety & Walkable neighborhood: pedestrian friendly \\
Mixed tenure & \\
Fair distribution of income & \\
Social order & \\
Social cohesion & \\
Community cohesion (i.e., cohesion between and & \\
among different groups) & \\
Social networks & \\
Social interaction & \\
Sense of community and belonging & \\
Employment & \\
Residential stability (vs. turnover) & \\
Active community organizations & \\
Cultural traditions &
\end{tabular}

Although their differentiation between non-physical and predominantly physical factors can be questioned, their tabular overview emphasizes the socio-spatial dimensions of urban social sustainability [45]. Furthermore, factors like "neighborhood", "community", or "active community organizations" already hint at discussions on the everyday urban life (cf. [45]). On this scale it is important in terms of analysis that socio-spatial exclusion differs from context to context. This aspect is reflected and further elaborated by Manzi et al. [42], stating that most concepts of social sustainability fail to appreciate the complexity of local political contexts so far [42]. By referring to Marcuse [16], they point out that social sustainability may uncritically imply conflict-free scenarios and an idealized vision of social consensus: "Therefore, the interdependent nature of social sustainability should acknowledge a political dimension; in particular by questioning how processes of power and control operate in urban policy contexts" [42]. This correlates closely with arguments that see an essential (and so far underrepresented) element of social sustainability in linking it with concepts of urban governance (see also [37], cf. especially [44]). Therefore, Dempsey et al. [45] call for an analytical focus on the neighborhood level itself, and Stren and Polèse [44] stress that

"the social sustainability of cities is affected not only by nationwide aspatial policies but also, if not chiefly, by policy decisions and implementation at the local level, often in sectors which $a$ priori appear to be relatively banal and prosaic. Local affairs do matter.” ([44], p. 17).

This bridging reflection on aspects of order, control and its associated actors and actor networks on the one hand and on the multi-scalar dimensions (neighborhood, metropole, nation, globe) of exclusion and social-sustainability on the other highlights the significance of the overall debate on urban governance as an analytical framework in social sciences and connects our paper to the theoretical framework. In South African cities, core issues of urban social sustainability and urban governance are set against the background of overcoming apartheid's socio-spatial fragmentation through urban integration. Influenced by a globalized competition between cities (as stated above), the peculiar structures of urban governance are closely linked to aspects of exclusion and marginalization, and 
therefore touch in a quite direct way the debate on urban social sustainability. Arguing along the dichotomy of "Global North" and "Global South", Colantonio [47] states that debates about urban social sustainability are embedded in 'hard' themes and discourses (e.g., equity, poverty, social justice) within cities of the south, while discourses linked to northern cities highlight 'soft' themes (e.g., participation, cohesion, quality of life). This questionable dualistic typology of urban problematizations becomes even more blurred in the South African context with its history of socio-spatial and socioeconomic "racialization". In this regard, Abbott [48], using the example of Cape Town, observes that "northern" as well as "southern" types of poverty can be traced within the South African city, depending on the formerly "racialized" group areas and their spatial imbalances. Following this differentiation of debates, the same can be stated for Johannesburg and eThekwini: political debates and related policies of social cohesion and the quality of life are similarly prominent as are those on social justice or on socioeconomic inequality - it all depends on the specific area of inquiry, i.e., on the type of neighborhood we are looking at.

Linking the overall debate on urban social sustainability with the South African context, the following three points of inquiry can be articulated (cf. [48]):

- Service delivery: Social equity in terms of access to public infrastructure, territorial justice, and housing (cf. [44,45])

- Democratization: Social inclusion with a decent quality of life/livelihood for all (cf. [35])

- Space: Spatial equality in terms of de-racialization and de-fragmentation (cf. [48])

On this basis, the following case studies help to clarify the correlation between urban governance, mega-event-driven development and urban social sustainability.

\section{On a Spectrum of Festivalisation: Hosting the World Cup in Johannesburg and eThekwini}

Implementing the World Cup is not a unidirectional process but can only be understood with respect to the existing structures of urban governance. Within the context of mega-event-driven development, these structures find themselves in a "state of emergency", which creates unique opportunities for decision-making, partly introducing new actors, blocking existing ones, enabling or disabling policies and so on. By terming it the "festivalisation of urban politics", Häußermann and Siebel [49] suggest that metropoles might generate opportunities and problems alike by purposefully inducing such developments. The preparation and the actual hosting of mega-events, in their view, leads to a concentration on the specific requirements of these projects and to a neglect of "ordinary" issues of urban management. Ironically though, by managing the hosting of these events, the actors of urban government try to prove their capacity to govern - which may even be successful, since in the course of the preparations all eyes are focused on the event itself and not on the day-to-day-business of "keeping the city alive". Besides this, what is hoped for is the strengthening of the citizens" identification with their city. On the other hand, the hosting of mega-events implies the risk of losing control over important spheres of government, since the pressure that is exerted on the actors and institutions involved in the preparations (e.g., due to the fixed timeframe) increases the willingness to rely on ad hoc solutions and on organizational arrangements that are not necessarily democratically legitimized - also creating opportunities for corruption [50]. 
Based on a research project on two South African host cities of the Football World Cup 2010, we have developed a hypothesis of various types of "Festivalisation". These represent the different possibilities on a spectrum of pathways of hosting an event on the urban governance scale and do produce different legacies in the hosting cities. The opposing poles unfolding this spectrum can be tagged as follows: On the one hand, considerable impacts on and changes in urban development - due to the hosting — can be tagged as "driven by the event" (Johannesburg has some features of this type), while on the other hand existing configurations of actors and a set of established policies were "driving the event" (eThekwini relates more to this configuration).

To illustrate the "driven by the event" type of festivalisation in Johannesburg, internal and external factors can be mentioned. The external event-related factors are: Johannesburg was the only city ever to host two FIFA World Cup stadiums, hosting the opening ceremony, the final match as well as the closing ceremony. Most of the international visitors arrived at OR Tambo international airport, which is located close to Johannesburg. Due to these circumstances there was a lot of pressure on the city from FIFA, as well as from the national government [51].

Besides this, internal factors rooted in Johannesburg's urban governance structure can be exemplified by the performance of the "2010 office" and its role in the implementation process. The office was established in 2005 and did coordinate all of the various city departments' event-related activities during the implementation process. The main aim was to speed up decisions and to shift around the bureaucratic hurdles. In contrary to eThekwini, this structure could not rely on experiences of prior ,mega-events and thus had only very few personal skills in handling big events. This had serious consequences on the mode of negotiation with FIFA. In retrospect, Christa Venter [52], one of the directors of the 2010 office described the situation as follows:

"We just accepted it. You know, it was very difficult to say no. [...] they have come with such a force, and you actually don't argue, because now you're still arguing and it takes two or three days to argue about one point and eventually you just say: OK let's just do it, you know, and sometimes it was very costly to do one of these things"

The same picture was drawn by a group of German consultants who visited the respective host cities from 2007 till 2010 several times. In Johannesburg they observed few attempts to discuss aspects of the host city agreement and renegotiate them with FIFA. As Thomas Jedlitschka [53], one of the consultants in Johannesburg stated: "The obedience to FIFA was very high in Johannesburg".

The type of festivalisation of urban governance along our proposed spectrum between "event-driven" and "driving the event" is not only expressed in the negotiation processes with external actors and the resulting translation of ideas into the local-metropolitan setting, but also by the way, the different spheres of government within the national setting are able to renegotiate their inter-governmental relations during the phase of the "state of emergency" which comes along with the festivalisation of urban governance. This is especially embodied within the specific setting of the Football World Cup and its dualistic role allocation of the "event-bringer" on the national level and the "event-hosts" on the metropolitan scale (cf. above). It is therefore of crucial importance to analyze the "shakiness" or "steadiness" of existing modes and structures of governance. This enables insights into how hosting cities added a surplus or end up in a zero-sum-situation (at best) concerning their existing urban 
development strategies and policies. Moreover, we argue that such a multi-facetted analysis offers possibilities to assess pathways for other upcoming host cities.

In this regard, hosting the World Cup in eThekwini differs from the situation in Johannesburg. In fact, driving events beyond metropolitan scales forms a basis for the city's strategy to compete with metropoles on a global scale, thus claiming the status of a world class city in tourism, sports, and conventions alike [54] (cf. [55-57]). This results in a certain "normality" of a more or less constant state of emergency in city politics on inner-city planning and development, which is strongly expressed in the smooth embedding of negotiating and steering the actual Football World Cup (cf. [58]). The Strategic Projects Unit 2010 (SPU), which formed the local steering body of the event's implementation, thereby consisted of personalities that were both, experienced in handling and managing the enormous challenges of mega-events, and were interwoven in place-related governance structures. This led to a situation where actors in the political and the managerial spheres were able to take short-cuts through the power structures of the different tiers of municipal government (i.e., the different departments and commissions) [59,60].

Despite the city's peripheral stance compared to Johannesburg and Cape Town, the SPU was well aware of the strategic position to function as a valuable hosting destination in terms of its all-year around warm climate and its huge potential to produce TV imageries with its kilometers-long beach promenade, the so-called Golden Mile [59]. This can be illustrated by the way the city put pressure on FIFA and the Local Organizing Committee on the national level to share the costs of 3.1 billion Rand (about 300 million USD) for the newly built Moses Mabhida Stadium with its iconic roof (see Figure 1) by otherwise upgrading the smaller rugby stadium instead and refusing to host up to seven matches including one semi-final (see also [58]).

Figure 1. eThekwini's Mhoses Mabhida Stadium with the old rugby stadium behind. Picture: M. Fleischer.

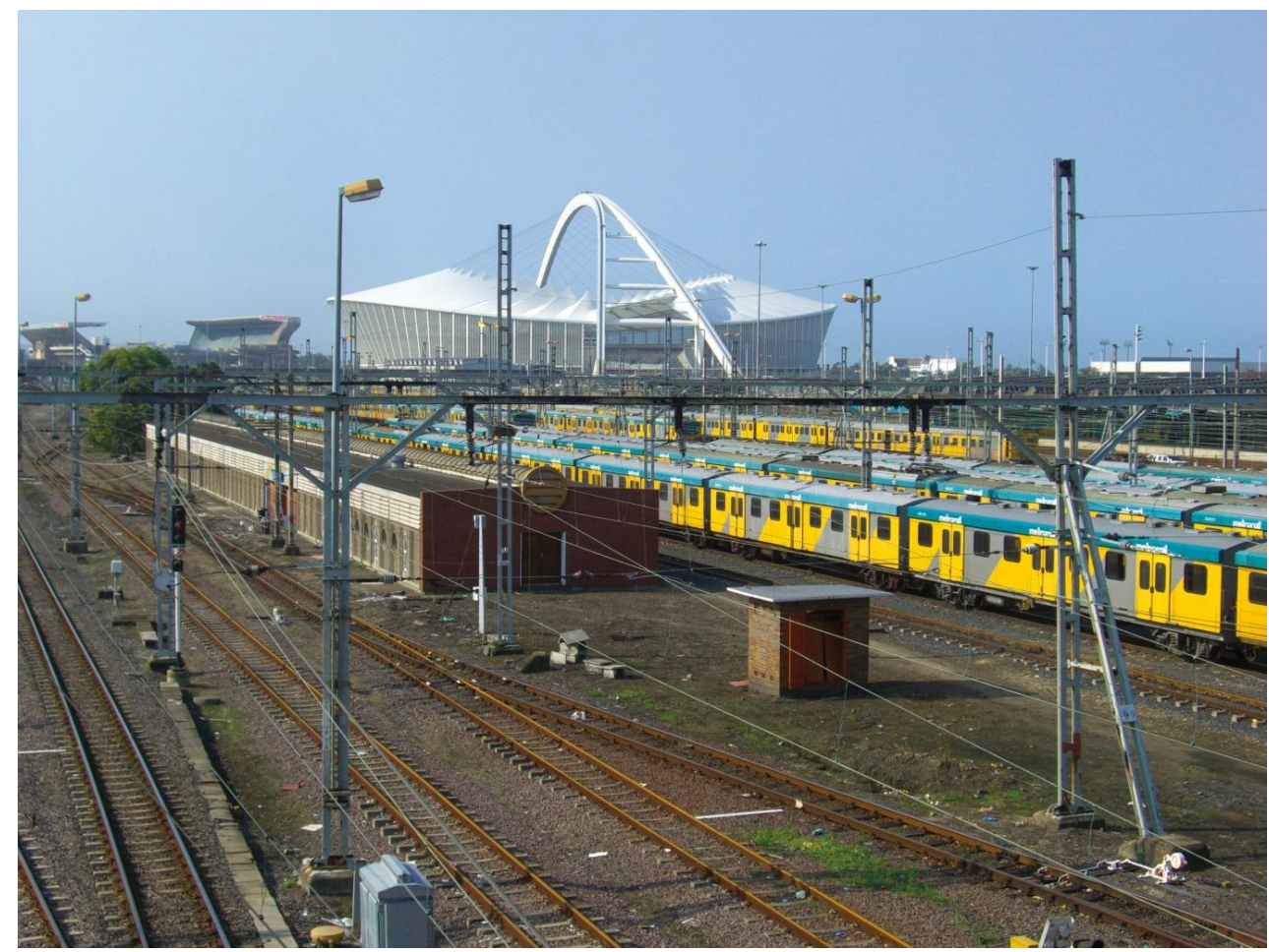


Beyond this, the strategic stance of being on a par with external actors did not only aim at World Cup-related projects like the stadium and its precinct itself, but also and especially on unlocking additional funding for other development projects within the city. To quote the head of the SPU:

"We would never work for Sepp Blatter. We work for the people of Durban. [...] FIFA, you are here to do an event, I am here to improve my city. Let us see what we can do. [...] Citizens of Durban are more important than them, they [the FIFA] come and they go. People of Durban live here every day." [59].

The most remarkable difference between the two host cities is the past experience in handling big events and the resulting confidence in the negotiation processes. Thus, we argue that the event was translated into very different city politics and affected these in different ways. While eThekwini used the event as a catalyst, the event functioned more as a distortion in Johannesburg. These two variations of festivalisation also have different consequences and effects for the lived realities of the respective residents at a local scale. Only the bringing together of both spheres provides a profound understanding of the process of mega-event implementation and its legacies. These different consequences are demonstrated by our local case studies in The Point/South Beach in eThekwini and Bertrams in Johannesburg.

\subsection{Johannesburg}

Bertrams, one of Johannesburg's oldest suburbs, located east of the inner city, underwent radical changes in the last twenty years. In apartheid times, this quarter was a "whites-only" group area with predominantly working class population. It has since turned into a poor immigrant neighborhood, although a substantial share of its former inhabitants is still living here in council housing (a government-subsidized housing scheme widely applied under apartheid). Bertrams today can be characterized as a social melting pot with problems like unemployment or drug abuse and an image coined by crime and grime (own observations shared by [61,62]).

Several of the one or two storey buildings dating back to the first decades of the 20th century are of heritage value. City actors and investors had interpreted this as a signifier for the neighborhood's huge potential for urban regeneration in the pre-World Cup period-besides the proximity to the Ellis Park sports precinct $[61,63,64]$. This discourse was accompanied by vast expectations of local residents, property owners, and businesspeople that prosperity and development would arrive in the wake of World Cup preparations.

In 2005 the City of Johannesburg released the Greater Ellis Park Development Plan (GEPD) promising a significant upgrade for the whole precinct to ensure the Ellis Park Stadium's fulfillment of requirements to host the 2010 FIFA World Cup [65]. The plans included several catalyst projects for Bertrams like housing upgrades, new shopping facilities, refurbishment of streets and the built environment, an artist village, new social projects and infrastructure investment [61]. Our field research carried out in 2012 revealed that most catalyst projects - except the Bus Rapid Transit System (BRT) and a private run cricket field [66] — had either not been implemented or were not in use anymore due to lack of maintenance. 
Yasmeen Dinath, working for the Department of Development Planning in the pre-World Cup period, describes the process as follows:

"[The] Ellis Park area [...] has gone into a complete state of disrepair because it was like a hitand-run type of approach. Short-term getting in there, get the infrastructure in there, spent the money make it look fine, but there was never enough planning and I suspect it the same for other 2010 projects. There was never enough initial planning, thinking about longer term, maintenance, sustainability longer term usage post World Cup [67].”

Monica Albonico, private consultant and architect who worked some years for the Johannesburg Development Agency and has known the area for 20 years refers to the original plans and sums up: "The whole 2010 destructed this whole process". She observed that the city only did what had priority for FIFA and the World Cup. Issues like social housing were left to the private sector [64].

Due to the enormous amounts of money used for the stadiums, the sports precinct and related infrastructure and due to the lack of experience and courage to renegotiate requirements with FIFA or, in other words, due to a driven-by-the-event implementation, the Johannesburg Development Agency (JDA) as implementing entity had hardly any capacity to steer the developments in the GEP. JDA thus concentrated their limited resources on World Cup related aspects. [68] The developments at the western part of the GEP place the consequences of this event driven implementation into a wider frame. Due to the enormous refurbishment of the sports precinct and due to the plans of the University of Johannesburg (UJ) to build several thousand student apartments in and beyond the education precinct, these neighborhoods underwent radical change and a remarkable uplift (see Figure 2). While there can be doubts if the investments of UJ were purely World Cup-related, the point we want to stress is, that due to the incapacity to use the event to steer urban development towards social sustainability, the spatial division between Bertrams and the neighboring quarters on its western side increased. A new city improvement district that is in its planning stage, which will include the Ellis Park Sports Precinct but exclude Bertrams, will intensify this development.

Summing up, it can be stated that the ambitious plans for a sustainable upgrading of the Greater Ellis Park precinct failed due to, basically, two major reasons and circumstances: First, the World Cup shifted most of the city's resources into World Cup-related projects, thus neglecting social issues, and dispossessing the City of the capacity to steer the developments - also for the post-event period [69]. Secondly, this led to a significant dependency on private investment and if the private sector shuns away from investment as in the case of Bertrams, no (sustainable) development takes place. Although the larger development scheme in Johannesburg can be characterized as property driven [70], analyzing the event reveals the decreasing capacity of the city to steer developments on the local level. In terms of social sustainability this type of urban governance might lead to an increasing spatial division in the following years - the GEP is a case in point. However, it is still too early to give a concluding answer to the question as to whether the event has had socially sustainable effects on the local level or not. However, we argue that the event encounters different governance structures, influencing them but also being subject to them: the effects of this dialectical process need to be discussed in the light of the concept of sustainability. 
Figure 2. World Cup-related developments in the Greater Ellis Park Precinct.

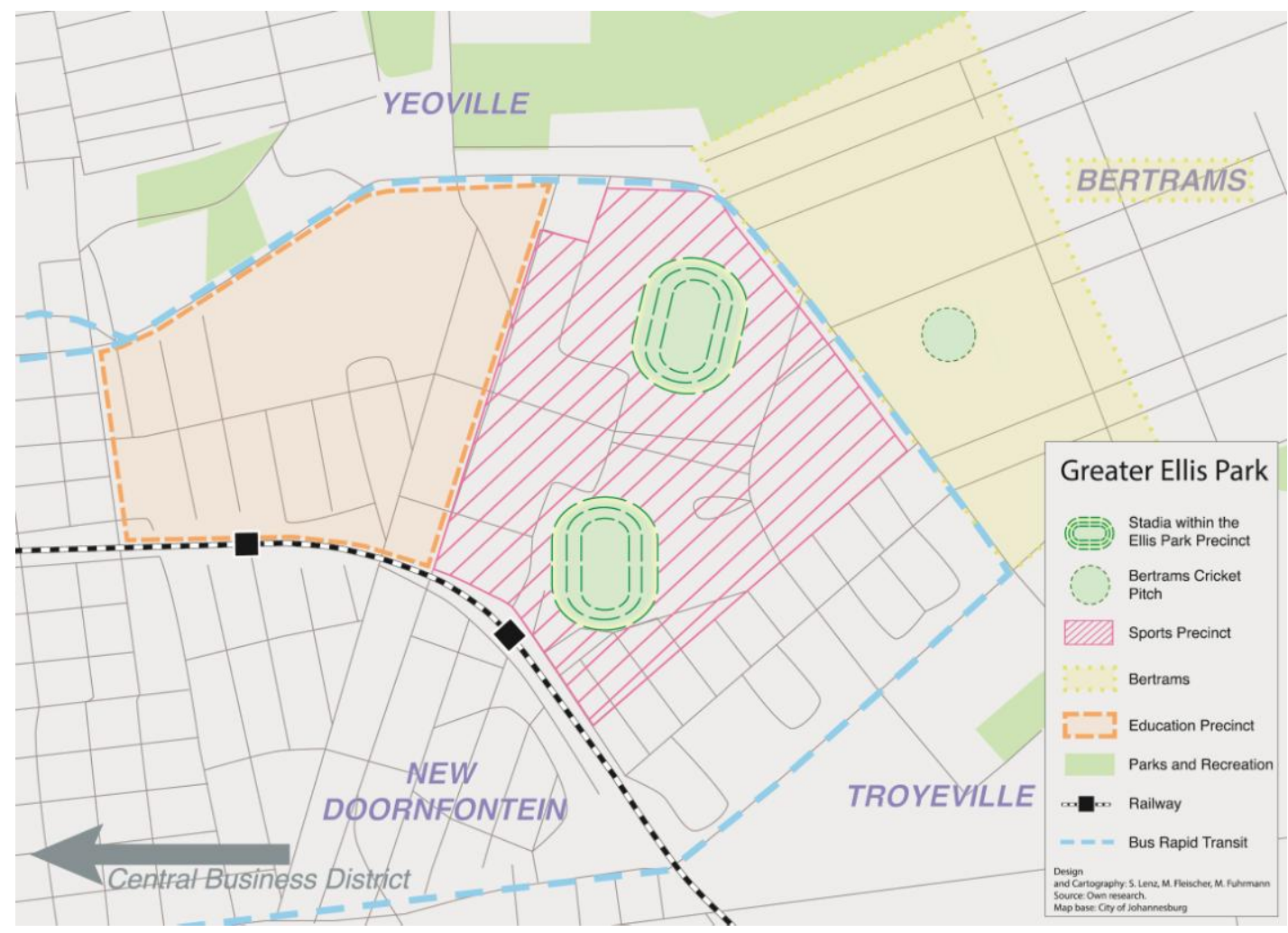

\section{2. eThekwini}

In terms of eThekwini's city politics on regeneration and renewal, a path-dependent history of "eventified" urban governance evolved, aimed at area-based interventions in urban development in the CBD and inner city areas (cf. [71]). Therefore, and with reference to the thesis of festivalisation mentioned above, eThekwini's history of driving events as means of city development not only evolved into city politics but the structures of urban governance became festivalized as well. Moreover, hosting this specific mega-event has been translated into urban politics that are stretching beyond the event-related policies, thus creating "lessons learnt" in terms of, e.g., medium- and longterm-economic development and service delivery [72].

Against this background of event-driven urban governance, our case study in eThekwini focuses on the Point/South Beach area, which forms the southernmost part of the inner city district and is situated along the recently revamped Beach Promenade, linking the Kings Park Sport Precinct (including the Moses Mabhida Football Stadium) in the north with the casino, the hotels, the uShaka Marine World (a Waterworld-style edutainment park and aquarium) and finally the Durban Point Waterfront in the south (see Figure 3). This area became the linchpin of inner-city World Cup related activities, offering a $4 \mathrm{~km}$ long walk along the shoreline from the stadium to the official Fan Fest on New Beach. However, it is necessary to add, that it has also represented a priority development zone since the decline of apartheid in the mid-1980s: The city's central business district with its adjacent Golden Mile was, as any other South African city, spatially "racialized", thus consisting of segregated places and amenities, i.e., "whites-only" beaches, hotels and residences. This was followed by the so-called "white flight", leaving behind slowly declining inner city parts of eThekwini, which in the case of the 
Point/South Beach is up until now an area, that can, according to statistics and public discourse, be termed as rather dodgy and crime-ridden $[73,74]$.

Figure 3. eThekwini's “Golden Mile” beach promenade and World Cup related developments.

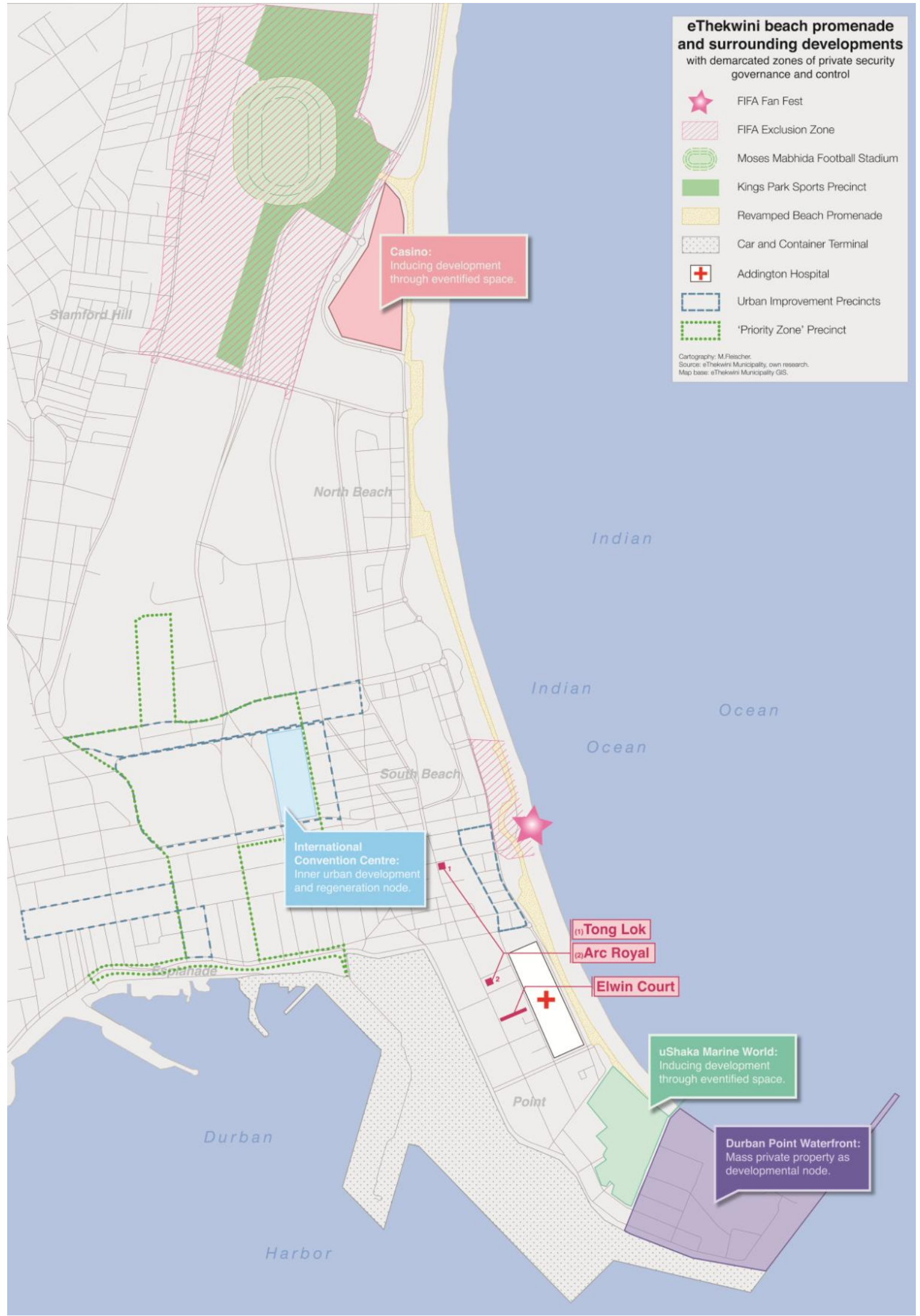


Therefore, creating a transect of urban redevelopment along the beach promenade by situating the Fan Fest to the southern tip of this transect can be seen as a prime example of eThekwini city politics using the World Cup as a facilitator of already existing development schemes:

"We got 350 Million [Rand] (clicks with her fingers) like that. When we used the words World Cup [...]. But then as soon as we started moving the fan park and we saw the resources we could get. (laughs) Like, wow, this is what we really need to do. [...] I don't think that the beachfront would have been done if we didn't put the fan park there. And that is the game. Sad reality. [...] So when this is the game we have to play, well then we will play it" [59].

The original budget for a redeveloped beachfront was around 15 million Rand [75]. Simply "branding" existing development projects as "FIFA-related" triggered an additional allocation of 335 Million Rand. These extended funds were provided by provincial and national governmental agencies through the above mentioned negotiation process between the Local Organizational Committee (LOC) and the SPU in eThekwini, where the latter insisted on an extended planning scope in turn for hosting a certain amount of football matches, including the semi-final [59].

This strategic positioning of event-related developmental nodes within the eThekwini municipality and its area-based strategies represent socio-spatial interventions aiming at a socially sustainable development of the city and its inhabitants through changes in urban governance and the built environment [71]. This in turn can be understood by taking a look at developments in proximity to the given locality (see Figure 3).

The examples (1) and (2) on the map, "Tong Lok" and "Arc Royal", are two of a number of "hijacked buildings", which were rather informally inhabited by low income households, creating unsecure spots in the area [76]. Both have now been vacated and closed up after a tedious negotiation process by the City [77]. One block further south is Elwin Court: A former state-owned social housing project that was transferred into a self-owned flat complex and body corporate. It is now dilapidated and virtually collapsing both in terms of building and social structure. A large number of its tenants have already received eviction notes while other households moved out earlier and partly sold the flats to investors [78]. The southern tip of the new beach promenade links up with uShaka Marine World which was already constructed in the early 2000s, functioning as an eventifying space to induce an increase in neighboring property value [79-81], thereby paving the way for a long planned waterfront development in this area which had been an inner-urban industrial wasteland before [82,83]. It is now a high priced residential area managed through a public-private partnership, and is embedded in a strategy to regenerate and revitalize the inner city (Gary Kimber, Strategic Projects Unit 2010, as cited in [84]).

The World Cup thus became a segment purposefully introduced into the larger urban development scheme within the inner city, including measures to tackle socio-spatial fragmentation, and often accompanied by regimes of securitization. This development includes the stadium precinct to the north, the International Convention Centre to the East and the Point Waterfront to the South aiming at a long-term improvement of inner city neighborhoods, especially of The Point (cf. Kimber, Strategic Projects Unit 2010, as cited in [84]). It thereby not only consists of interventions in the built environment but also challenges the socio-spatial reality by introducing new actors, institutions, modes of spatial appropriation and perception, as well as 'materiality'. All this takes place in a highly fragmented local arena and along transecting corridors (the beachfront or the movement patterns 
between uShaka and the Waterfront). A multiplicity of actors and institutions is thus woven into a manifold setting of urban governance and embedded into area-based development strategies to make use of events for urban development.

\section{Discussion}

It has become a common feature of the aftermath of mega-events that different actors (academics and politicians alike) present a variety of reports about the (more or less) sustainable effects of the specific event [85] which also applies for the Football World Cup in South Africa [10,86-90]. Nevertheless, and with reference to the conceptual debate, urban social sustainability needs to be understood as a qualifier of existing policies and governance structures concerning their relation to socio-spatial equality and social justice. By calling to mind that a more concrete and applicable definition of social sustainability can be found by associating it with its polar opposite of social exclusion, our research project on the festivalisation of urban governance and the production of dis-/order in South African cities after the World Cup contributes to the larger discussion on mega-event development and social sustainability. Being an ex-post research, the featured case studies of this article started from observable effects in event-related development in Johannesburg and eThekwini in order to retrace the ways, existing modes of governance were distorted, catalyzed, or invented through what we term "festivalisation". In this regard, the article offers insights into cases of mega-event related urban developments in South African cities by asking the question, how and by whom socio-spatial dis-/order is produced, translated and manifested in the metropolitan and the local sphere of post-apartheid urban societies. As stated in the beginning, the effects of mega-event hosting on urban development have to be understood in the light of respective strengths and weaknesses of the specific types of urban governance in any given host city. It is these structures, which form the modus operandi within the processes of dis-/ordering, thus transforming order as desired predictabilities into observable effects [91] (see Figure 4).

Figure 4. Urban Governance and the production of dis-/order through event-driven urban development.

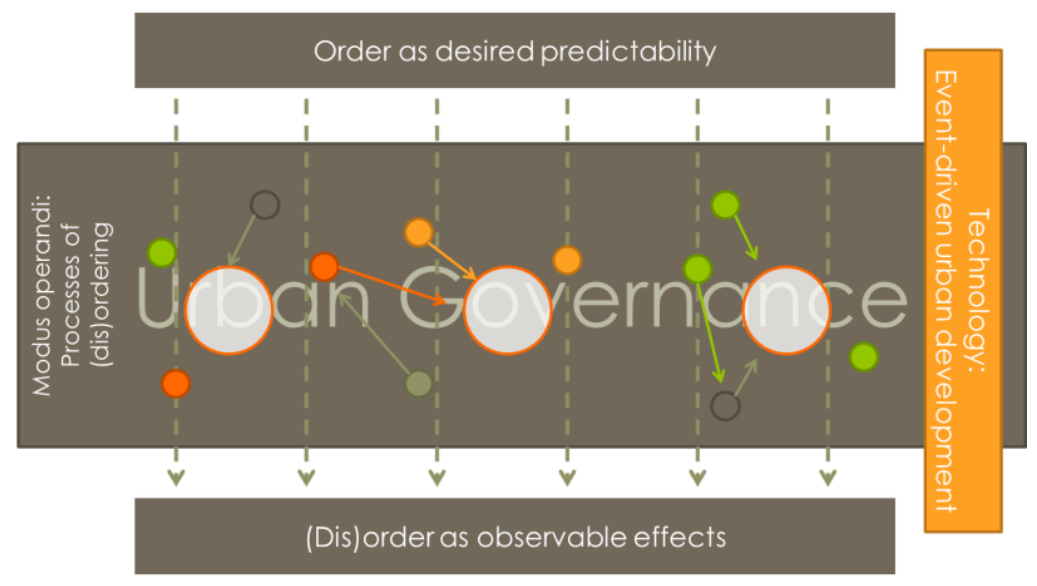

What does this mean for the interrelation of urban governance, social sustainability, and eventdriven development? To elaborate on this question, we first want to return to the above-mentioned 
central aspects on urban social sustainability in South African cities (service delivery, democratization, and space) and contextualize them against the background of the present cases on event-driven interventions and the spectrum of festivalisation, before tying the debate back to the literature on urban social sustainability:

\subsection{Service Delivery}

Both examples highlight a tendency in festivalized governance to prefer medium- to large-scale interventions with a focus on landmark projects or necessities for the event's content provider (e.g., the beach promenade and Point/South Beach area-based redevelopment in eThekwini), which strengthen the influence of private investors on public space and services (which is strongly the case in Johannesburg). Interestingly, depending on the type of festivalisation, the balance between public and private interventions seemed to have significantly shifted. While the "driven by the event" situation on governance structures in Johannesburg primarily gave leeway to the private sphere, the situation eThekwini was different: while bringing more private actors into the scene on the level of investment, the reins of planning and development seemed to have rested in 'strong hands' on the metropolitan level. The tight linkages between the political actor network and the private sector in the municipality even appear to have been boosted during the implementation of the mega-event. Nevertheless, post-event outcomes need further and prolonged assessment, partly due to the fact that the actor-institution settings do not necessarily last. Meanwhile, in both local arenas, aspects of social equity in terms of public infrastructure, territorial justice and housing can be termed as being highly ambivalent in their outcomes as the logics of event-driven governance do not seem to suit the fine-grained urban fabric of the manifold urban spaces and its inhabitants.

\subsection{Democratization}

With the implementation of the Football World Cup and its bringing about of developmental nodes, the differences in the quality of life increased and accumulated in certain areas in relation to buildings and/or neighborhoods in direct proximity, thus contradicting the need for governance structures which promote social inclusion and a livelihood for all (cf. [35]). This is highlighted by the Johannesburg case study on a meso-scale, while the eThekwini case reveals micro-scalar evidence. This coincides with what Smith [33] mentions by pointing to the ambivalent situation deriving from event-driven development which can on the one hand shift additional resources into "projects in the pipeline", but can on the other hand lead to "authoritarian governance", resulting from the event's tight time constraints. This is the case in eThekwini, where the festivalized politics and the creation of the SPU as a cross-cutting agency brought about intervention which is creating a "Golden Curtain" along the Golden Mile, hiding the differences in the quality of everyday life. Moreover, our research reveals that the overall setting of mega-event driven development and festivalized urban governance does not lead to desirable outcomes in terms of achieving democratic structures and participation processes in South African cities, even though the situation in eThekwini still appears to offer at least some sort of democratic engagement. Still, this trend highly depends on the type of festivalisation as well as the institutional level, leaving especially the neighborhood sphere in possible despair. 


\subsection{Space}

Against the specific background of the post-apartheid city, both aforementioned aspects culminate in the third factor: the socio-spatial dimension within the production of dis-/order in relation to the normative approach of a socially sustainable society. In the light of mega-event-driven development, new forms of spatial exclusion and inclusion through cultural and socio-spatial commodification emerge, which can be understood in the light of the revanchist city [33,92,93]. Here, Kearns and Forrest [94] with their contribution on multi-level urban governance and social cohesion add a fruitful link to urban space, bringing together the production of social order and civic culture with urban design and management of public spaces. They observe a tendency of redevelopment of public urban space under the terms of "hegemony of middle-class civic culture and social order", which neglects social and cultural diversity. Although our case studies reflecting such homogenizing effects are brought about by mega-event driven developments, they also point to a differentiation relating to the specific settings of urban governance and, as we argue, to the type of festivalisation. In this regard, implementing the World Cup led to ambiguous results concerning the socio-spatial transformations, though it can be observed that they reflect the overall state of social sustainability in urban development and planning in each case irrespective of the event-related interventions (cf. [14]). Conceptually spoken, this can be understood in the light of the logics of festivalisation of urban governance, where the event itself does not necessarily imply positive or negative effects on urban policies and institutions, but certainly intensifies existing, path-dependent modes of governance [95]. Hence in terms of the thematic setting of post-apartheid geographies in South African metropoles, both cases of mega-event driven interventions had an overall homogenizing effect on urban space in terms of capital investment, thus leading to a certain defragmentation in terms of mainstreaming the cityscape along the line of entrepreneurial 'world class urban space'. This in turn implies the potential to exclude those that are already excluded and marginalized, thus questioning a long-term goal of a socially just and equal society (cf. [96]).

Manzi et al. [42] emphasize that establishing a socially sustainable society remains a fundamental goal of our time. Referring to Marcuse [16] they continue by stating that "the principles need to be clarified and the elasticity of the concept needs to be defined more effectively to produce useful practical strategies; in particular, the concept needs to consider the central question of equity and to "emphasize the criterion of long-term political and social viability in the assessment of otherwise desirable programs and not as a goal replacing social justice, which must remain the focal point of our efforts" (emphasis added). In addition and as we try to highlight, the way how societies evolve and exist in urban settings is mainly influenced by the way that cities are steered through the structures of governance. Those in turn do not emerge solely from institutions on a higher level in a unilateral way, but form a matrix of translations and adaptations of different ideas and regimes of governance from the metropolitan to the neighborhood level. This is especially evident in the case of South Africa's post-apartheid cities with their path-dependent history of segregation along the lines of the former, institutionalized "racial" divisions. 


\section{Future Perspectives: A Hegemony of Festivalized Middle-class Civic Culture on the Rise?}

The mega-event of the Football World Cup had been traveled through powerful global actors into the different localities of the host cities where the process of translation and adaptation differed in relation to the urban governance configuration ant the associated type of festivalisation. However this process does not seem to happen in a solely one-way perspective, nor is it limited to the South African example. Public protests in Brazil related to the hosting of the Confederations Cup in June 2013 (an event that is traditionally organized by the host of the FIFA Football World Cup in the year that precedes this mega-event) may indicate a changing international perception of the value of this type of festival. It is interesting to note, that, besides demands for better public transport and for upgrades in urban infrastructure, issues of social justice have also been raised.

In this regard, the critique formulated by Kearns and Forrest [94] does not only apply to the featured case studies, but can be extended by attributing a "hegemony of festivalized middle-class civic culture" to the world class city desire, brought about by the mega-event related processes within the respective structures of governance. In the case of South Africa with its still highly fragmented cityscape, a continuance of the festivalisation of urban governance could contest the normative goal of creating a socially sustainable society that is moving beyond the apartheid legacy. Those processes may not originate from mega-event developments but surely evolve in the wake of enduring trends in festivalisation of urban governance. Therefore and with the increasing number of mega-event host cities in the "Global South", the lessons that can be learned from the South African cases can be seen in the remaining and sometimes intensified fragmentation of city-space in terms of increased socio-spatial exclusion. Mega-events in an age of global urban competition and a growing desire for becoming world class cities thus challenge the call for social sustainability in terms of social justice. This does not happen directly through the event itself, but through the influences of this technology within the processes of dis-/ordering, bringing along micro-effects on the local level which are connected to a global-local network of actors and institutions, making it even more difficult for the affected to directly intervene in associated developments. Therefore, the analytical work within the debate on urban social sustainability in the light of mega-event driven development must continue to focus on local arenas, policies, institutions, and modes of governance, "even though the broader forces conditioning the dynamic of urban change incorporate complex elements from larger and more inclusive systems" [44].

\section{Conflicts of Interest}

The authors declare no conflict of interest.

\section{References and Notes}

1. Heyne, M. Die ökonomischen Effekte von Fußballweltmeisterschaften: Das Beispiel "FußballWM 2006" (in German); Tactum: Marburg, Germany, 2006.

2. Naßmacher, H. Baustelle Stadt: Effizienz und Bürgernähe ohne Demokratie und Nachhaltigkeit (in German)? VS Verlag für Sozialwissenschaften: Wiesbaden, Germany, 2006. 
3. Lenskyi, H.J. The Best Olympics Ever? Social Impacts of Sydney 2000; University of New York Press: Albany, NY, USA, 2002.

4. Burbank, M.J.; Andranovich, G.D.; Heying, C.H. Olympic Dreams: The Impact of Mega-Events on Local Politics; Lynne Rienner Publishers: Boulder, CO, USA, 2001.

5. Ehrenberg, E.; Kruse, W. Soziale Stadtentwicklung durch große Projekte? EXPOs, Olympische Spiele, Metropolen-Projekte in Europa: Hannover, Sevilla, Barcelona, Berlin (in German); Lit Verlag: Münster, Germany, 2000.

6. Geipel, R.; Helbrecht, I.; Pohl, J. Die Münchner Olympischen Spiele von 1972 als Instrument der Stadtentwicklungspolitik. In Festivalisierung der Stadtpolitik. Stadtentwicklung durch große Projekte (in German); Häußermann, H., Siebel, W., Eds.; Westdeutscher Verlag: Opladen, Germany, 1993; pp. 278-304.

7. Obermair, C. ITALIA 93-eine verpasste Chance der Stadtpolitik? In Festivalisierung der Stadtpolitik. Stadtentwicklung durch große Projekte (in German); Häußermann, H., Siebel, W., Eds.; Westdeutscher Verlag: Opladen, Germany, 1993; pp. 208-229.

8. Haferburg, C.; Steinbrink, M. Mega-Event und Stadtentwicklung im globalen Süden: Die Fußballweltmeisterschaft 2010 und ihre Impulse für Südafrika (in German); Brandes \& Apsel Verlag: Frankfurt am Main, Germany, 2010.

9. Steinbrink, M.; Haferburg, C.; Ley, A. Festivalisation and urban renewal in the Global South: Socio-spatial consequences of the 2010 FIFA World Cup. S. Afr. Geogr. J. 2011, 93, 15-28.

10. South African Football Association (SAFA). 2010 Bid Book; Unpublished work, 2004.

11. Republic of South Africa (RSA). The White Paper on Local Government, Department of Constitutional Development, Ed.; Republic of South Africa: Pretoria, South Africa, 1998.

12. Albert Speer \& Partner GmbH (AS\&P). Sport- und Grossveranstaltungen: Sport and Mega Events (in German); AS\&P: Frankfurt am Main, Germany, 2013.

13. Haferburg, C. South Africa under FIFA's reign: The World Cup's contribution to urban development. Dev. S. Afr. 2011, 28, 333-348.

14. Haferburg, C.; Fleischer, M.; Fuhrmann, M.; Krüger, F. Post World Cup Effects and Urban Local Re-Generation Strategies in Johannesburg and Durban. In Urban Governance in Post-Apartheid Cities; Haferburg, C., Huchzermeyer, M., Eds.; Gebrüder Bontraeger: Berlin, Germany, 2014, forthcoming.

15. Burris, S.; Kempa, M.; Shearing, C. Changes in Governance: A Cross-Disciplinary Review of Current Scholarship. Akron Law Rev. 2008, 41, 1-66.

16. Marcuse, P. Sustainability is not enough. Environ. Urban. 1998, 10, 103-112.

17. One major aspect - in administrative terms - of the early stage in the post-apartheid transition phase was the reorganization of the municipal structures under the Local Government Municipal Structures Act 1998 (see: Harrison, P.; Todes, A.; Watson, V. Planning and Transformation: Learning from the Post-Apartheid Experience; Routledge: Abingdon, UK, 2008.). Through this, the former City of Durban merged with surrounding municipalities into the eThekwini Metropolitan Municipality. Nevertheless, administrative changes are not always reflected in terms of "casual usage". "Durbanites", the inhabitants of what is now officially called eThekwini, still use the former name (Durban) in the same manner as the new name (eThekwini). This contradiction in place naming is reflected in parts of the literature as well as the consistent 
labeling by FIFA as the host city Durban. Throughout this chapter, reference to the eThekwini Metropolitan Municipality will be made by the use of "eThekwini".

18. Oranje, M. Neoliberalism, Shallow Dreaming and the Unyielding Apartheid City. In Contradictions of Neoliberal Planning; Tasan-Kok, T., Baeten, G., Eds.; Springer: Dordrecht, The Netherlands, 2012; pp. 173-204.

19. Lindell, I.; Hedman, M.; Nathan-Verboomen, K. The World Cup 2010 and the urban poor: 'World class cities' for all? Available online: http://urn.kb.se/resolve?urn=urn:nbn:se:nai:diva1170 (accessed on 12 November 2013).

20. Cornelissen, S. Internationalisation and competitiveness in South African urban governance: On the contradictions of aspirationist urban policy-making. In State of the Nation: South Africa 2008; Kagwanja, P., Kondlo, K., Eds.; HSRC Press: Cape Town, South Africa, 2009; pp. 226-250.

21. Landman, K. Gated Minds, Gated Places: The Impact and Meaning of Hard Boundaries in South Africa. In Gated Communities; Bagaeen, S., Uduku, O., Eds.; Earthscan: London, UK, 2010; pp. 49-62.

22. Simone, A. The Politics of Urban Intersection: Materials, Affect, Bodies. In The New Blackwell Companion to the City, 1st ed.; Bridge, G., Watson, S., Eds.; Blackwell Publishing Ltd: Oxford, UK, 2011; pp. 357-366.

23. Bénit-Gbaffou, C. Police-community partnerships and responses to crime: Lessons from yeoville and observatory, Johannesburg. Urban Forum 2006, 17, 301-326.

24. Harrison, P.; Todes, A.; Watson, V. Planning and Transformation. Learning from the Post-Apartheid Experience; Routledge: Abingdon, UK, 2008.

25. Harvey, D. From Managerialism to Entrepreneurialism: The Transformation in Urban Governance in Late Capitalism. Geogr. Ann. Ser. B 1989, 71, 3-17.

26. Harvey, D. Spaces of Capital: Towards a Critical Geography; Edinburgh University Press: Edinburgh, UK, 2001.

27. Zukin, S. David Harvey on Cities. In David Harvey: A Critical Reader; Castree, N., Gregory, D., Eds.; Blackwell Publishing: Malden, MA, USA, 2006; pp. 102-120.

28. Surborg, B.; vanWynsberghe, R.; Wyly, E. Mapping the Olympic growth machine. City 2008, 12, $341-355$.

29. Andranovich, G.; Burbank, M.J.; Heying, C.H. Olympic Cities: Lessons Learned from Mega-Event Politics. J. Urban Aff. 2001, 23, 113-131.

30. Kassens-Noor, E. Transport Legacy of the Olympic Games, 1992-2012. J. Urban Aff. 2013, 35, 393-416.

31. Czarniawska, B.; Joerges, B. Travels of Ideas. In Translating Organization Change; Czarniawska, B., Sevón, G., Eds.; De Gruyter: Berlin,Germany, 1996; pp. 13-48.

32. Smith, A. Theorising the Relationship between Major Sport Events and Social Sustainability. J. Sport Tourism 2009, 14, 109-120.

33. Smith, A. The Relationship between Major Events, the Urban Fabric and Social Sustainability. In Social Sustainability in Urban Areas, Communities, Connectivity and the Urban Fabric; Manzi, T., Lucas, K., Lloyd-Jones, T., Allen, J., Eds.; Earthscan: London, UK, Washington, DC, USA, 2010; pp. 199-219. 
34. World Commission on Environment and Development (WCED). Report of the World Commission on Environment and Development: Our Common Future; Oxford University Press: Oxford, UK, 1987.

35. Koning, J. Social Sustainability in a Globalizing World: Context, Theory and Methodology Explored. In More on MOST: Proceedings of an Expert Meeting, The Hague, The Netherlands, September 2002; van Rinsum, H.J., de Ruijter, A., Kazancigil, A., Alagh, Y.K., Genov, N., Koning, J., Siebers, H., Eds.; Unesco Centre the Netherlands: The Hague, The Netherlands, 2002; pp. 63-89. Available online: http://digital-library.unesco.org/shs/most/gsdl/collect/most/index/ assoc/HASH01fd/f53dc033.dir/doc.pdf (accessed on 20 October 2013).

36. Partridge, E. 'Social Sustainability': A Useful Theoretical Framework? In Proceedings of Australasian Political Science Association Annual Conference, Dunedin, New Zealand, 27-30 September 2005.

37. Cuthill, M. Strengthening the 'social' in sustainable development: Developing a conceptual framework for social sustainability in a rapid urban growth region in Australia. Sustain. Dev. 2010, 18, 362-373.

38. Vallance, S.; Perkins, H.C.; Dixon, J.E. What is social sustainability? A clarification of concepts. Geoforum 2011, 42, 342-348.

39. Bramley, G.; Dempsey, N.; Power, S.; Brown, C. What Is 'Social Sustainability', and How Do Our Existing Urban Forms Perform in Nurturing It? In Proceedings of Planning Research Conference, London, UK, 5-7 April 2006.

40. Coleman, J.S. Social Capital in the Creation of Human Capital. Am. J. Sociol. 1988, 94, S95-S120.

41. Putnam, R.D. Bowling alone: America's decline in social capital. J. Democr. 1995, 6, 65-78.

42. Manzi, T.; Lucas, K.; Lloyd-Jones, T.; Allen, J. Understanding Social Sustainability: Key Concepts and Developments in Theory and Practice. In Social Sustainability in Urban Areas, Communities, Connectivity and the Urban Fabric; Manzi, T., Lucas, K., Lloyd-Jones, T., Allen, J., Eds.; Earthscan: Lodon, UK, Washington, DC, USA, 2010; pp. 1-28.

43. Yiftachel, O.; Hedgcock, D. Urban social sustainability: The planning of an Australian city. Cities 1993, 10, 139-157.

44. Stren, R.E.; Polèse, M. Understanding the New Sociocultural Dynamics of Cities: Comparative Urban Policy in a Global Context. In The Social Sustainability of Cities: Diversity and the Management of Change; Polèse, M., Stren, R.E., Eds.; University of Toronto Press: Toronto, Canada, 2000; pp. 4-38.

45. Dempsey, N.; Bramley, G.; Power, S.; Brown, C. The social dimension of sustainable development: Defining urban social sustainability. Sustain. Dev. 2011, 19, 289-300.

46. Colantonio, A. Social Sustainability: Linking Research to Policy and Practice. In Proceedings of Sustainable Development: A Challenge for European Research, Brussels, Belgium, 26-28 May 2009.

47. Colantonio, A. Urban Social Sustainability: North - South Perspectives. In the UN-Habitat 4 th World Urban Forum, Nanjing, China, 3-6 November 2008.

48. Abbott, J. Cape Town: Seeking Social Sustainability in a Fast-Growing City. In The Social Sustainability of Cities: Diversity and the Management of Change; Polèse, M., Stren, R.E., Eds.; University of Toronto Press: Toronto, Canada, 2000; pp. 280-307.

49. Häußermann, H.; Siebel, W. Festivalisierung der Stadtpolitik. Stadtentwicklung durch große Projekte (in German); Westdeutscher Verlag: Opladen, Germany, 1993. 
50. Häußermann, H.; Siebel, W. Stadtpolitik (in German); Suhrkamp: Frankfurt am Main, Germany, 2008.

51. Nkhahle, S. Acting Executive Director at the South African Local Government Association (SALGA) (former coordinator of host cities in the South African Cities Network (SACN)), Johannesburg, South Africa. Oral interview, 2012.

52. Venter, C. Director of the 2010 Office, City of Johannesburg, South Africa. Oral interview, 2012

53. Jedlitschka, T. Former Consultant for "Kommunen in der einen Welt", counsellor-at-law, Berlin, Germany. Oral interview, 2012

54. The hosting of festivals and events on national as well as international scale is fairly common for the eThekwini Municipality, e.g., the "One City, Many Cultures Festival", the yearly festive season between Christmas and New Year, the Comrades Marathon or, of global importance, the hosting of the A1 Grand Prix as well as conferences such as COP17-CMP or BRICS Summit.

55. Maharaj, B.; Pillay, V.; Sucheran, R. Durban-A subtropical coastal paradise? Tourism dynamics in a post-apartheid city. Available online: http://etudescaribeennes.revues.org/1192 (accessed on 20 November 2013).

56. Alegi, P. 'A Nation to Be Reckoned With': The Politics of World Cup Stadium Construction in Cape Town and Durban, South Africa1. Afr. Stud. 2008, 67, 397-422.

57. Todes, A. Reintegrating the Apartheid City? Urban Policy and Urban Restructuring in Durban. In A Companion to the City; Bridge, G., Watson, S., Eds.; Blackwell Publishing: Malden, MA, USA, Oxford, UK, Victoria, AU, USA, 2000; pp. 617-629.

58. Sole, S. Durban's Moses Mabhida Stadium: Arch of hope or yoke of debt? In Player and Referee. Conflicting Interests and the 2010 FIFA World Cup, Schulz-Herzenberg, C., Ed.; South African Institute for Security Studies: Pretoria, South Africa, 2010; pp. 169-201.

59. Ellingson, J.-M. Head of Strategic Project Unit 2010, eThekwini, South Africa. Oral interview, 2012.

60. Layman, A. CEO Durban Chamber of Commerce and Industry, eThekwini, South Africa. Oral interview, 2012.

61. Albonico, M.; Sack, N.; Mzumara, M. Presentation: Greater Ellis Park Development Implementation Stage, Bertrams Derby Road; City of Johannesburg: Johannesburg, South Africa, 2005.

62. Ley, A. "Friede den Stadien, Krieg den Hütten?" Strategische Stadtinszenierung versus soziale Wohnungsbaupolitik in Südafrika. In Megaevent und Stadtentwicklung im globalen Süden: Die WM 2010 und ihre Impulse für Südafrika (in German); Haferburg, C., Steinbrink, M., Eds.; Brandes \& Apsel Verlag: Frankfurt am Main, Germany, 2010.

63. Gedye, L. What World Cup? Mail and Guardian, 6-12 October 2006.

64. Albonico, M. ASM Architects and Urban Designers, Johannesburg, South Africa. Oral interview, 2012.

65. Albonico, M.; Sack, N.; Mzumara, M. Presentation: Executive Summary Presentation Precinct Planning Component; ASM Architects and Urban Designers: Johannesburg, South Africa, 2005.

66. The Johannesburg Cricket club initiated this remarkable project. The club implemented a social sports project integrating the community of Bertrams and is $100 \%$ responsible for the maintenance of the facilities.

67. Dinath, Y. Former Assistant Director Strategic Spatial Planning-Region F, City of Johannesburg, South Africa. Oral interview, 2012.

68. For the implementation of the GEPD, two billion Rand (about 190 million USD) were actually required whereas JDA had only calculated $8 \%$ of this amount. Further $48 \%$ were expected to be contributed by private initiatives and $44 \%$ by other city or national entities (see: Bénit-Gbaffou, C. 
In the Shadow of 2010: Democracy and Displacement in the Greater Ellis Park Development Project. In Development and Dreams: The Urban Legacy of the 2010 Football World Cup; Pillay, U., Tomlinson, R., Bass, O., Eds.; HSRC Press: Cape Town, South Africa, 2009; pp. 200-222.). While the actual expenditure for the stadiums rose from calculated 1.5 billion Rand (about 140 million USD) in 2005 to more than 4 billion (about 390 million USD), the calculated 414 million Rand for the Ellis Park precinct shrank to 64 million in actual expenditure (cf. City of Johannesburg. Delivering a Promise; City of Johannesburg: Johannesburg, South Africa, 2010.).

69. After the World Cup large parts of the city development came to a standstill. Leslie Magoro, head of the regional housing department, states: "What is actually happening since the World Cup came and gone, we no longer have that budget. We only had that budget prior to the 2010 World Cup. Now there's hardly a cent".

70. Murray, M.J. City of Extremes: The Spatial Politics of Johannesburg; Wits University Press: Johannesburg, South Africa, 2011.

71. Pillay, C. Effecting Transformation through Area-Based Management: The Case Study of eThekwini Municipality, Durban, South Africa. In Proceedings of N-AERUS XII Conference of Network-Association of European Researchers on Urbanization in the South, on The City at a Human Scale, Madrid, Spain, 20-22 October 2011.

72. eThekwini Municipality. Annual Report 2009/2010; eThekwini Municipality: eThekwini, South Africa, 2009.

73. eThekwini Municipality. Area based Management and Development Programme, eThekwini Municipality. Available online: http://www.durban.gov.za/Documents/City_Government/Area_ Based_Management/ABM\%20Crime\%20and\%20Justice.pdf (accessed on 18 November 2013).

74. Griggs, R.A. An Evaluation of Nine Pilot Sites to Propose a South African Model of Community Prosecution. Available online: http://justiceforum.co.za/CPI-evaluation.asp (accessed on 18 November 2013).

75. Capmon Internet. eThekwini Project Profile for 100km Beachfront; Project Profiles 2006/2007. Available online: http://capmon.durban.gov.za/reports/project_finance/wrdstrp3.asp?project_id= 2829 (accessed on 18 November 2013).

76. Nene, D. Safer Cities Central eThekwini (Durban), eThekwini, South Africa. Oral interview, 2012.

77. Moola, H. eThekwini (Durban) iTrump Area Based Management, eThekwini, South Africa. Oral interview, 2012.

78. Grundler, A. High Court Appointed Administrator for Elwin Court, eThekwini (Durban). eThekwini, South Africa. Oral interview, 2013.

79. Brink, C.P. Point Marine Theme Park Feasability Study; Moreland Developments: eThekwini, South Africa, 2001; Volume 1.

80. Shearing, C. Reflections on the Refusal to Acknowledge Private Governments. In Democracy, Society and the Governance of Security; Wood, J., Dupoint, B., Eds.; Cambridge University Press: Cambridge, UK, 2006; pp. 11-32.

81. Shearing, C.; Stenning, P.C. From the Panopticum to Disney World: The Development of Discipline. In Perspectives in Criminal Law: Essays in Honour of John Ll. J. Edwards; Doob, A.N., Greenspan, E.L., Eds.; Canada Law Book: Toronto, Canada, 1985; pp. 335-349.

82. uShaka is the catalyst to open the Point Area. The Star, 29 July 2003. 
83. Grant, L.; Scott, D. Waterfront developments as tools for urban reconstruction and regeneration in South Africa. Urban Forum 1996, 7, 125-138.

84. Gounden, K. Waterfront Development as a Strategy for Urban Renewal: A Case Study of the Durban Point Waterfront Development Project; University of KwaZulu-Natal: Durban, South Africa, 2010.

85. Flyvbjerg, B. Public Planning of Mega-Projects: Overestimating of Demand and Underestimating of Costs. In Decision-Making on Mega-Projects: Cost-Benefit Analysis, Planning and Innovation; Priemus, H., Flyvbjerg, B., Van Weese, B., Eds.; Edward Elgar Publishing: Cheltenham, UK, 2008; pp. 120-144.

86. Cottle, E. A Preliminary Evaluation of the Impact of the 2010 FIFA World Cup in South Africa; Schweizerisches Arbeiterhilfswerk: Bern, Switzerland, 2010.

87. Cottle, E. South Africa's World Cup-A Legacy for Whom? University of KwaZulu-Natal Press: eThekwini, South Africa, 2011.

88. Gerrans, L. Green Goal Legacy Report; City of Cape Town: Cape Town, South Africa, 2011.

89. Death, C. 'Greening' the 2010 FIFA World Cup: Environmental Sustainability and the MegaEvent in South Africa. J. Environ. Pol. Plann. 2011, 13, 99-117.

90. Human Science Research Council (HSRC). Impact of the 2010 World Cup on Social Cohesion, Nation Building and Reconciliation; HSRC: Pretoria, South Africa, 2011.

91. This partly derives from the meta-conceptual work of the DFG-funded Priority Program "Adaptation and Creativity in Africa - Significations and Technologies in the Production of Order and Disorder". The research project "Festivalisation of urban governance" on which this article is based upon formed part of this program and is aiming at investigating the effects of the 2010 World Cup on the urban sphere, and on society, in South Africa. For further information see: http://www.spp1448.de/projects/projects-phase-i/festivalisation-of-urban-governance/.

92. Helms, G.; Belina, B. "The friendly eye in the sky"-Neuordnungen der Städte durch Kontrollpolitik in Großbritannien. In Großbritannien: Geographien eines europäischen Nachbarn (in German); Zehner, K., Wood, G., Eds.; Spektrum Akademischer Verlag: Heidelberg, Germany, 2010; pp. 167-175.

93. MacLeod, G. From Urban Entrepreneurialism to a "Revanchist City"? On the Spatial Injustices of Glasgow's Renaissance. Antipode 2002, 34, 602-624.

94. Kearns, A.; Forrest, R. Social Cohesion and Multilevel Urban Governance. Urban Stud. 2000, 37, 995-1017.

95. Haferburg, C.; Steinbrink, M. Anstöße (in German). In Mega-Event und Stadtentwicklung im globalen Süden. Die Fußballweltmeisterschaft 2010 und ihre Impulse für Südafrika; Haferburg, C., Steinbrink, M., Eds.; Brandes \& Apsel Verlag: Frankfurt am Main, Germany, 2010; pp. 10-24.

96. Harvey, D.; Potter, C. The Right to the Just City. In Searching for the Just City: Debates in Urban Theory and Practice; Marcuse, P., Connolly, J., Novy, J., Olivio, I., Potter, C., Steil, J., Eds.; Routledge: London, UK, New York, NY, USA, 2009; pp. 40-51.

(C) 2013 by the authors; licensee MDPI, Basel, Switzerland. This article is an open access article distributed under the terms and conditions of the Creative Commons Attribution license (http://creativecommons.org/licenses/by/3.0/). 